\title{
GPPS-BJ-2019-0074
}

\section{RICH-LEAN COMBUSTOR FOR A 50KW CLASS MICRO GAS TURBINE FIRING AMMONIA}

\author{
Norihiko Iki, Osamu Kurata, Takahiro Inoue, \\ Takayuki Matsunuma \\ Affiliation Energy Technology Research \\ Institute, \\ National Institute of Advanced Industrial \\ Science and Technology (AIST) \\ n-iki@aist.go.jp \\ Tsukuba, Ibaraki, Japan
}

\section{Masato Kawano, Keisuke Arai Toyota Energy Solutions Inc.} m-kawano@toyota-turbine.co.jp Toyota, Aichi 471-8573, Japan

\author{
Taku Tsujimura, Hirohide Furutani \\ Fukushima Renewable Energy Institute, AIST \\ (FREA) \\ tsujimura-taku@aist.go.jp \\ Koriyama, Fukushima, Japan
}

\author{
Hideaki Kobayashi, Akihiro Hayakawa, \\ Ekenechukwu Okafor \\ Institute of Fluid Science, Tohoku University \\ kobayashi@ifs.tohoku.ac.jp \\ Aoba-ku, Sendai, Miyagi, Japan
}

\begin{abstract}
Hydrogen production is expected as the useful energy storage technology for fluctuation of renewable energy. Ammonia is expected to be a hydrogen carrier that has potential as a carbon-free fuel. Ammonia is known as a nonignitable fuel, and it is not easy to hold ammonia flames under atmospheric conditions. A demonstration test with the aim of showing the potential of ammonia-fired power plants was conducted using a micro gas turbine. A 50-kW-class turbine system firing kerosene was selected as a base model. More than $40 \mathrm{~kW}$ of power generation was achieved by firing ammonia gas or a mixture of ammonia and methane by modifying the combustor, the fuel control device, and the gas turbine start-up sequence. The prototype bi-fuel combustor is a swirl combustor employing a non-premixed flame and a decreased air flow rate near a gas fuel injector for flame holding. Ammonia combustion in the prototype bi-fuel combustor was enhanced by supplying hot combustion air and by modifying the air inlets. However, the exhaust gases from the ammonia flames had high NOx concentrations. NOx removal equipment using selective catalytic reduction can reduce NOx emission levels to below $10 \mathrm{ppm}$ from more than $1,000 \mathrm{ppm}$ (converted value of $\mathrm{NOx}$ to $15 \% \mathrm{O}_{2}$ ) as already reported. However, downsizing of NOx removal equipment should be achieved for practical use. Therefore, a low NOx combustor was developed. We modified the combustor to the rich-lean burning method and found the condition that the NO
\end{abstract}

emission can be reduced to less than half, but the NOx emission reduction was insufficient as compared with the small-scale flow test at the lab scale. Therefore, each part of the combustor was redesigned so that mixing of fuel and air improves uniformity. Low-NOx combustor (Step2) was designed using knowledge of Prototype bi-fuel combustor for ammonia (Step0) and Low-NOx combustor (Step1). As a result, we found a condition that the NO emission can be reduced to $1 / 4$ or less as compared with before redesigning for rich-lean combustion.

\section{INTRODUCTION}

Hydrogen production is expected as the useful energy storage technology for fluctuation of renewable energy such as solar power and wind power without responding to the power demand. Hydrogen carriers are an important technology for increasing renewable-energy use. Ammonia is expected to be a hydrogen carrier and has potential as a carbon-free fuel. Main issues of ammonia combustion are combustion efficiency and NOx emission. Ammonia is known as a nonignitable fuel, and it is not easy to hold an ammonia flame under atmospheric conditions. Hayakawa et al. measured the laminar burning velocity of an ammonia-air mixture. The maximum value of the laminar burning velocity is only $7 \mathrm{~cm} / \mathrm{s}$, which is $1 / 5$ of the laminar burning velocity of the methane-air mixture (Hayakawa et al., 2015a). 
Research and development of gas turbines firing ammonia were tried in 1960s (Pratt, 1867; Solar Division of International Harvester Company, 1968). However, the measured combustion efficiency was unacceptably low for gas turbine operation and ammonia combustion produces much nitrogen oxide, NOx. In the 1970s, pollution problems became a major issue. Therefore, ammonia was considered unsuitable for fuel. Recently, ammonia was used in selective catalytic reduction (SCR) systems for reduction of NOx in exhaust gases of Diesel engines and thermal electric power stations. The problem of NOx emissions from ammonia-fired engines has become solvable. Therefore, recently, ammonia research as a fuel is becoming popular (Valera-Medina, 2018). Development of power plants firing ammonia have started in several countries. Evans proposed the concept of an ammoniafueled power plant and carried out combustor tests (Evans, B. 2013). Valera-Medina et al. researched a gas turbine combustor firing ammonia and methane (Valera-Medina, A. et al. 2015; Valera-Medina, A. et al. 2017). Ito et al. tested a gas turbine combustor firing methane and ammonia (Ito, S. et al., 2015; Ito, S. et al. 2016). Uchida et al. tried large eddy simulation (LES) of a gas turbine firing methane and ammonia mixtures (Uchida, M. et al., 2016).

The National Institute of Advanced Industrial Science and Technology (AIST) and Tohoku University demonstrated a micro gas turbine firing ammonia as a small model of gas turbine power generation to show the possibility of power generation from ammonia combustion (Iki, N. et al., 2014; Iki, N. et al., 2015a; Kurata, O. et al., 2015; Iki, N. et al. 2015b; Iki, N. et al. 2016a; Kurata, O. et al., 2017a; Kurata, O. et al., 2017b; Iki, N. et al. 2016b; Iki, N. et al. 2017a; Iki, N. et al. 2017b; Iki, N. et al. 2017c). A 50-kW class turbine system firing kerosene was selected as a base model. The gas turbine was redesigned for ammonia combustion by modifying the combustor, fuel control device, and gas turbine start-up sequence. The prototype bi-fuel combustor (Step0) is a swirl combustor employing a non-premixed flame and decreased air flow rate near the fuel injector for flame holding. Ammonia combustion was enhanced in the prototype bi-fuel combustor by supplying hot combustion air and modifying the air inlets. The redesigned gas turbine could generate electric power by firing ammonia with kerosene. Although the exhaust gases from ammonia combustion had a high NOx concentration, the SCR unit could reduce NOx emission significantly (Iki, N. et al., 2014; Iki, N. et al., 2015a; Kurata, O. et al., 2015). More than $40 \mathrm{~kW}$ of power was generated by firing ammonia gas or a mixture of ammonia and methane (Iki, N., et al. 2015b; Iki, N., et al. 2016a; Kurata, O. et al., 2017a; Kurata, O. et al., 2017b). This prototype gas turbine could achieve low NOx emissions using the SCR unit. However, the level of NOx emission of this prototype gas turbine without the SCR is remarkably higher than the usual power generation plants. Therefore, in the next step of the project, AIST and Tohoku University tried to develop an ammonia combustion technology that enables both better flame stability and lower NOx emission in the gas turbine combustor. Short term goal is achievement of 200ppm of $\mathrm{NOx}$ at $16 \% \mathrm{O}_{2}$ without SCR. This goal and development of new catalyst for SCR can reduce size and cost of SCR unit remarkably in several years. Flame observation in the gas turbine combustor was tried to grasp the state of the ammonia flame (Iki, N. et al. 2016b; Iki, N. et al. 2017a) . A combustor test rig was prepared for the development of the low NOx combustor and was used to check the performance of the combustor (Iki, N. et al. 2017b; Iki, N. et al. 2017c). This paper reports the results of the low NOx combustors with the combustor test rig and power generation with gas turbine.

\section{Low-NOx Combustion}

Hayakawa et al. showed the NO formation/reduction mechanisms of ammonia-air premixed flames at various equivalence ratios and pressures (Hayakawa, A. et al., 2015b). The mole fraction of NO decreases with an increase in the equivalence ratio near stoichiometric condition. Somarathne et al. report suitable equivalence ratio for low NOx emission (Somarathne, Kunkuma, K. D., 2016; Somarathne, Kunkuma, K. D., 2017). Therefore, the concept of rich-lean combustion, which is the combination of $\mathrm{NH}_{3}$-rich combustion in the primary combustion zone and lean combustion of the remaining fuel in the secondary combustion zone, enables low NOx emission in a swirl combustor, such as a gas turbine combustor.

Although the redesigned gas turbine with the prototype bi-fuel combustor emitted high NO, the maximum value was below $2000 \mathrm{ppm}$ at $15 \% \quad \mathrm{O}_{2}$. The $\mathrm{NO}$ conversion ratio decreased with an increase in $\mathrm{NH}_{3}$ concentration in a binary fuel of ammonia and methane. The concentration of ammonia in the binary fuel was expressed as a ratio of the low heating value of ammonia to the sum of the lower heating values of the two fuels (Kurata, O. et al., 2017a). In the cases of kerosene-ammonia combustion and methane-ammonia combustion, the ammonia gas supply increases NOx in the exhaust gases dramatically. NO emission peaked at an ammonia heat fraction of 0.6 (Kurata, O. et al., 2017a; Iki, N. et al., 2017a). Temporal and spatial flame fluctuations were observed. Therefore, it was estimated that NOx concentration in the combustor may fluctuate temporally and spatially (Iki, $\mathrm{N}$. et al., 2017a). The emissions of $\mathrm{NO}$ and $\mathrm{NH}_{3}$ clearly depend on the combustor inlet temperature at a rotating speed of 75,000 rpm (Kurata, O. et al., 2017a; Iki, N. et al., 2017a) . Nevertheless, air cooling of the combustor liner was as necessary for the prototype bi-fuel combustor as it was for the gas turbine combustor. The flows in the gas turbine combustor are complicated enough to develop an entirely new low-NOx combustor. Therefore, redesigning of the prototype bi-fuel combustor for rich-lean combustion was tried. The combustor test rig was prepared for the development of low-NOx combustors. Several parts of the prototype bi-fuel combustor (step0) were modified for the prototype low-NOx combustor. The emission of the prototype combustors for a $50 \mathrm{~kW}$-class micro gas turbine firing ammonia-kerosene was investigated by using the combustor test rig (Iki, N., et al., 2018). The prototype low-NOx combustor could decrease NOx emissions below half of the NOx emissions of the prototype bi-fuel combustor. The prototype low-NOx combustor could decrease $\mathrm{NH}_{3}$ and $\mathrm{N}_{2} \mathrm{O}$ emissions significantly. However, the prototype 
low-NOx combustor is not suitable for long time operation of the micro gas turbine due to starting-up procedure. AIST, Toyota Energy Solutions Inc. and Tohoku University manufactured the new low-NOx combustor (Step1) and actual power generation was performed (Kurata, O. et al., 2019) . In order to avoid destruction of the gas turbine, it is necessary to modify on the cooling structure of the combustor step by step. As Step1 is the first trial version of rich-lean combustor for micro gas turbine, the tried modification of the cooling structure of Step 1 is limited.

This paper reports the further modification of low-NOx combustor for lesser NOx emission. The experimental data of the NOx emission were obtained in the case of the operation by firing only ammonia.

\section{Table 1 Specification of base micro gas turbine}

\begin{tabular}{|c|c|}
\hline Manufacturer & $\begin{array}{c}\text { Toyota Turbine and System Inc. (Current } \\
\text { Toyota Energy Solutions Inc.) }\end{array}$ \\
\hline Cycle & Regenerative cycle \\
\hline Shaft & Single shaft \\
\hline Compressor & Centrifugal one-stage \\
\hline Turbine & Radial one-stage \\
\hline Rotating Speed & $80,000 \mathrm{rpm}$ \\
\hline Electric Power Output & $50 \mathrm{~kW}$ \\
\hline Fuel & Kerosene \\
\hline Combustor & Single can, \\
& Diffusion combustion \\
\hline
\end{tabular}

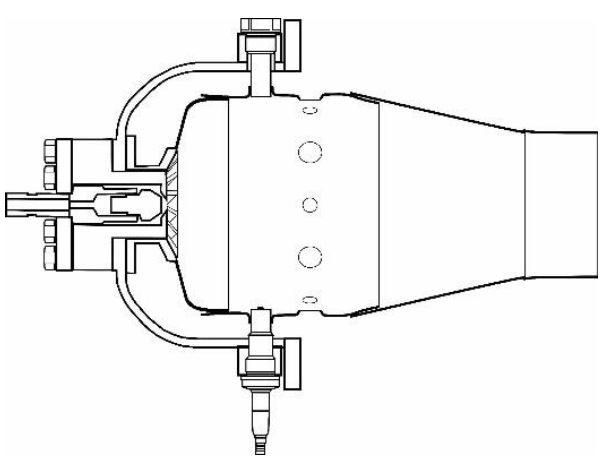

(a) Original combustor for kerosene (Iki, N., et al., 2016a)

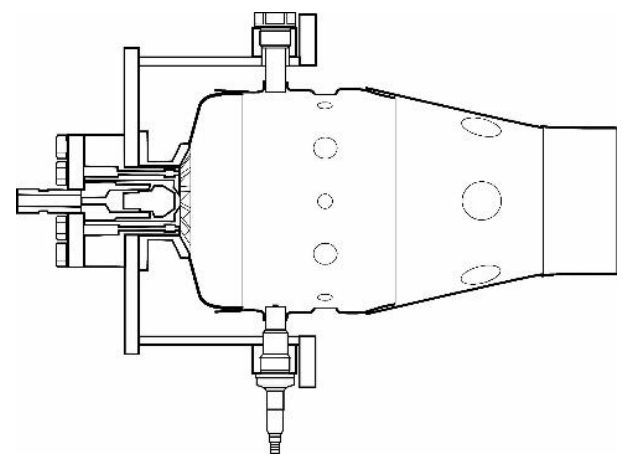

(b) Prototype bi-fuel combustor for ammonia (Step0) (Iki, N., et al., 2016a)

Figure 1. Prototype Combustor

\section{EXPERIMENTAL APPARATUS}

\section{Micro gas turbine}

A $50 \mathrm{~kW}$ class micro gas turbine was selected as the base engine of ammonia fueled gas turbine. The specification of this gas turbine is shown in table 1.

Exhaust gases were sampled at the upstream side of the SCR unit. FTIR (Fourier transform infrared spectroscopy, BOB-200FT from Best Instruments Co. Ltd.) was employed for exhaust gas measurement. Keyence data logger NR-600 was employed for temperature measurement.

Its standard swirl combustor is replaced by prototype swirl combustors which enables bi-fuel supply of kerosene and gas fuel as shown in figure 1. The combustor inlet air was heated by the recuperator using gas turbine exhaust energy from the gas turbine. A conventional swirl injector for kerosene is set in the center of the combustor inlet. Ammonia

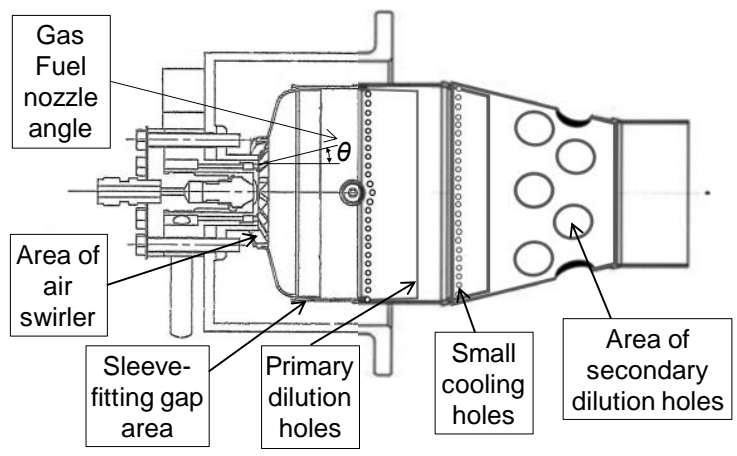

(a) Redesign points

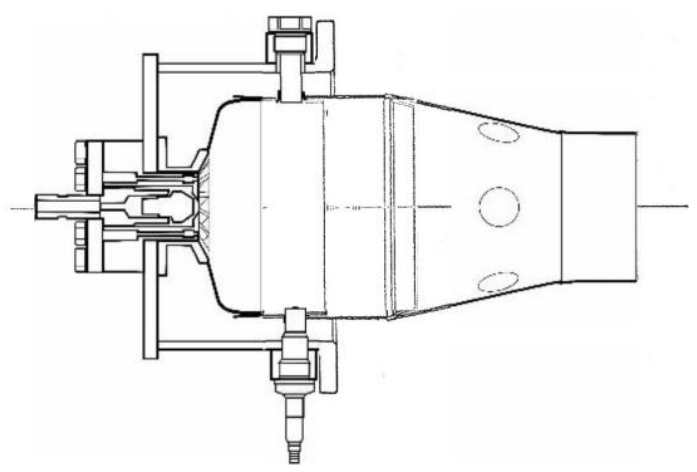

(b) Low-NOx combustor (Step1)

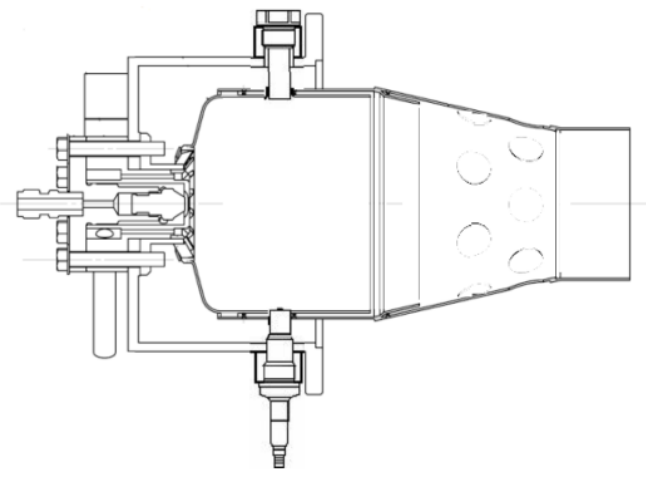

(c) Low-NOx combustor (Step2)

Figure 2. Low NOx Combustors 
gas is supplied from 12 holes of the fuel gas injector outside of the kerosene injector. This fuel gas injector produces nonpremixed flame for easier flame holding. Since the laminar burning velocity of ammonia is lower than that of methane gas, air flow rate in the combustor was decreased using bypasses of air flow by making large holes in the combustor liner. Therefore, pressure drop of the combustors for ammonia (fig.1 (b)) is not as large as that of the original combustor (fig.1 (a)). The higher temperature limit of the combustion air at recuperator exit was 630 degrees $C$ for heat protection of the recuperator. The gas turbine was started by firing kerosene and stable power generation was achieved. Then fuel gas supply was started gradually. Kerosene supply decreased with increase of fuel gas supply in order to hold flame.

\section{Low-NOx Combustor}

The prototype bi-fuel combustor for ammonia combustion (Step0) employed non-premixed flame for flame stability. Then the Prototype low NOx combustors were tested in the combustor test rig (Figure 2). The purpose of this redesigning of the prototype bi-fuel combustor is to find the low NOx combustion condition and to examine the effect of the rich-lean combustion on the combustor.

Therefore, the redesigned combustor might not start up the gas turbine or may extinguish flame in the process from start-up to the power generation operation. Therefore, the lowNOx combustor (Step1) was designed using the several knowledges of the prototype low NOx combustor in the combustor test rig. The low-NOx combustor (Step1) demonstrated the potential of rich-lean concept on low-NOx emission. In the case that area of secondary dilution holes is 2times of Step0, NOx reduction effect is observed and NOx emission level takes local minimum around $20 \mathrm{~kW}$ of electrical power output [26]. In the case that area of secondary dilution holes is 1.5times of Step0, NOx reduction effect is also observed. However, combustor liner temperature reaches to
1,000 degrees $\mathrm{C}$ around $32 \mathrm{~kW}$ of electric power output before NOx emission level takes local minimum. The available maximum temperature of the combustor liner of this gas turbine is 1,000 degrees $\mathrm{C}$. These results show that the combustor liner cooling is important issue on rich-lean concept. NOx emission decreases with increase of fuel nozzle angle in the case of for Step1.

Then low-NOx combustor (Step2) was designed by improving the combustor liner cooling of primary combustion zone as shown in fig. 1(d) and table 2. To achieve lesser NOx emission, several parameters were tested. Number of secondary dilution holes are increased for reduction of circumferential nonuniformity of combustion air supply. In the case of case1 NOx reduction effect may be expected at higher electric power output when combustor liner cooling is succeeded. In the case of case 2 lowest NOx emission may be expected around 20kW of electric power output like Step1. These parameters are shown in table 2, such as gas fuel nozzle angle, hole size of gas fuel nozzle, area of secondary dilution holes for combustion air, area of air swirler.

Gas fuel nozzle angle was 45 degree at the maximum for step1 and NOx emission is the lowest when Gas fuel nozzle angle was 45 degree. Therefore 60 degree of gas fuel nozzle angle was also tested. The distance along the nozzle hole axis between the nozzle exit and the combustor liner of nozzle becomes short. Therefore, area of fuel gas nozzle hole is increased due to reduce the velocity of the fuel gas.

Total area of secondary dilution holes for combustion air is same value as that of step1 when NOx emission effect was observed. Area of air swirler inlet can be varied by adding the ring. Area of air swirler inlet is same value as that of step1 when NOx emission effect was observed at first (case1, case2). And area of air swirler inlet is same value as step0 (case3).

Table 2 Combustor design

\begin{tabular}{|c|c|c|c|c|c|c|c|c|}
\hline & $\begin{array}{c}\text { Primary } \\
\text { dilution } \\
\text { holes }\end{array}$ & $\begin{array}{l}\text { Area of } \\
\text { air swirler }\end{array}$ & $\begin{array}{c}\text { Sleeve- } \\
\text { fitting gap } \\
\text { area }\end{array}$ & $\begin{array}{c}\text { Small cooling } \\
\text { holes }\end{array}$ & $\begin{array}{l}\text { Number of } \\
\text { secondary } \\
\text { dilution holes }\end{array}$ & $\begin{array}{c}\text { Area of } \\
\text { secondary } \\
\text { dilution holes }\end{array}$ & $\begin{array}{c}\text { Gas Fuel } \\
\text { nozzle angle }\end{array}$ & $\begin{array}{c}\text { Area of Gas } \\
\text { Fuel nozzle } \\
\text { hole }\end{array}$ \\
\hline orisinal & With & 1 & without & with & 0 & 0 & & 1 \\
\hline Step0 & With & 1 & without & with & 6 holes & 1 & $0^{\circ}$ & 1 \\
\hline Step1[25] & Without & Decrease & with & $\begin{array}{l}\text { Air emitting } \\
\text { near end of } \\
\text { primary } \\
\text { combustion } \\
\text { zone }\end{array}$ & $6 \sim 12$ holes & $1,1.5,2$ & $0^{\circ}, 30^{\circ}, 45^{\circ}$ & 1 \\
\hline Step2 & \multirow{8}{*}{ Without } & & \multirow{8}{*}{ Newly } & \multirow{8}{*}{$\begin{array}{l}\text { Ar emitting to } \\
\text { secondary } \\
\text { combustion } \\
\text { zone }\end{array}$} & & & & \\
\hline $\begin{array}{l}\text { Case1a } \\
\text { Case1b }\end{array}$ & & $\begin{array}{l}\text { Decrease } \\
\text { Decrease }\end{array}$ & & & $\begin{array}{l}12 \text { holes } \\
12 \text { holes }\end{array}$ & $\begin{array}{l}1.5 \\
1.5\end{array}$ & $\begin{array}{l}45^{\circ} \\
60^{\circ}\end{array}$ & $\begin{array}{l}1.2 \\
1.2\end{array}$ \\
\hline Case2a & & Decrease & & & 16 holes & 2 & $45^{\circ}$ & 1.2 \\
\hline Case2a' & & Decrease & & & 16 holes & 2 & $45^{\circ}$ & 1 \\
\hline Case2b & & Decrease & & & 16 holes & 2. & $60^{\circ}$ & 1.2 \\
\hline Case3a & & 1 & & & 16 holes & 2 & $45^{\circ}$ & 1.2 \\
\hline Case 3a' & & 1 & & & 16 holes & 2 & $45^{\circ}$ & 1 \\
\hline Case3b & & 1 & & & 16 holes & 2 & $60^{\circ}$ & 1.2 \\
\hline
\end{tabular}




\section{RESULTS}

The experimental condition of the micro gas turbine was changed by setting the rotating speed and power output. Although control of equivalence ratio of primary combustion zone is important for rich-lean concept, flow rate of combustion air is mainly controlled by rotating speed and flow rate of fuel is mainly controlled by setting of power output. Higher combustor inlet temperature gives higher primary combustion zone temperature and it may give higher combustor liner temperature. Therefore, too high combustor inlet temperature may limit the allowed operational range of

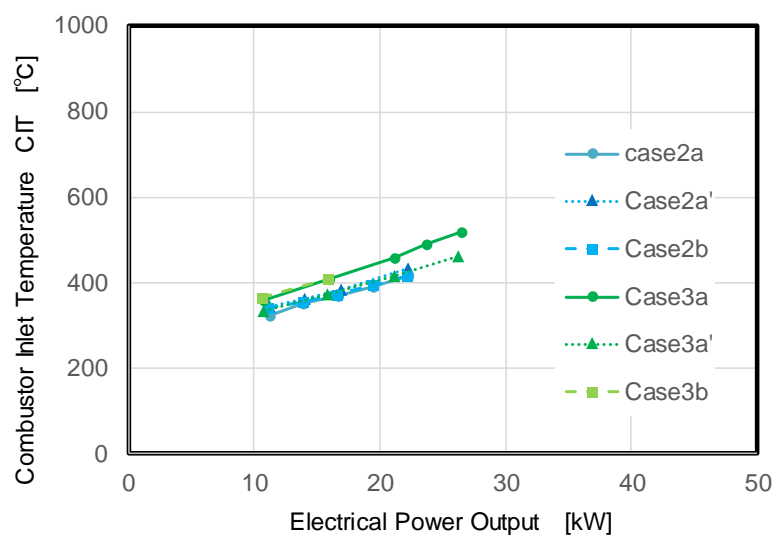

(a) 70,000rpm

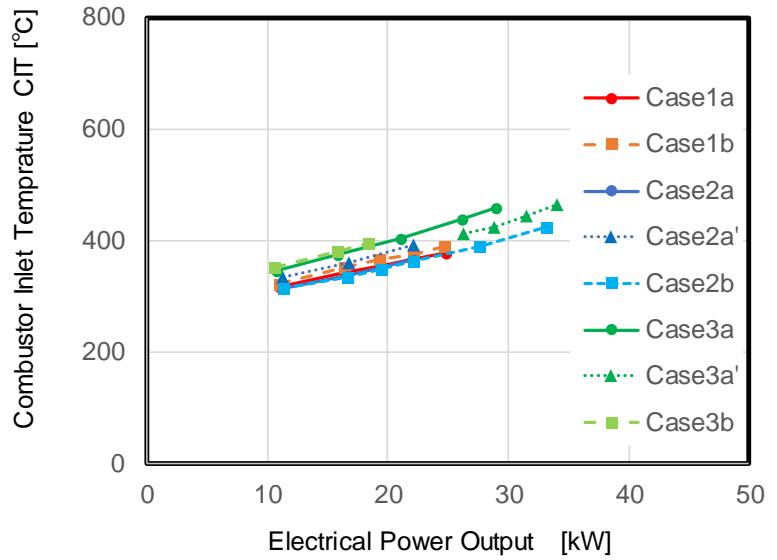

(b) $75,000 \mathrm{rpm}$

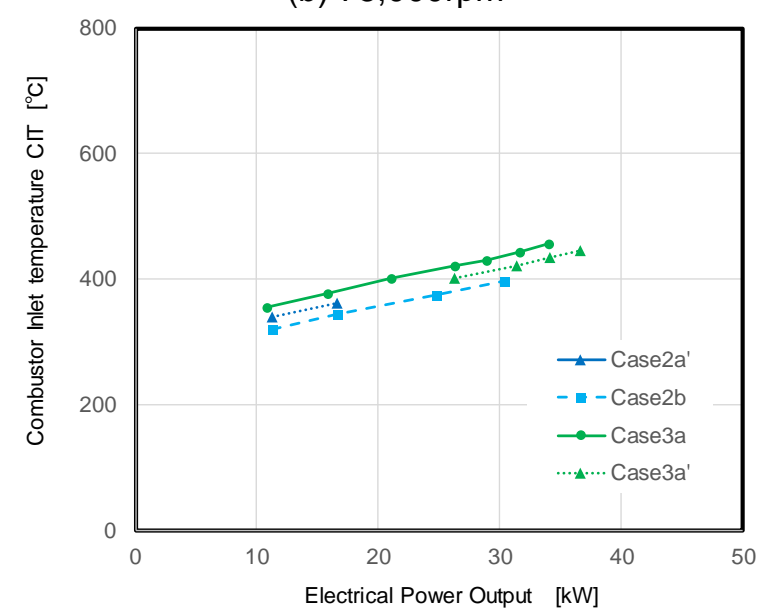

(c) $80,000 \mathrm{rpm}$

Figure 3. Combustor Inlet Temperature the micro gas turbine due to the higher limit of liner temperature in the case of suitable equivalence ratio of primary combustion zone for low NOx emission. In that case combustor liner cooling system should be redesigned. The operational range of micro gas turbine of the low NOx combustor Step 1 was limited, combustor liner cooling system was redesigned.

Figure 3 shows combustor inlet temperature of combustion air. In each case, combustor inlet temperature increases with electrical power output. Although the difference between cases includes effects of weather condition (atmospheric pressure, temperature, wetness), there is a trend that the rotating speed reduce combustor inlet temperature. The range of combustor inlet temperature is not so different with that of micro gas turbine with low NOx combustor Step 1. Figure 4 shows emission before SCR and highest value of combustor liner temperature. NO emission accounts for about $90 \%$ of total NOx emission. NO emission increases with electric power output and expected NOx reduction effect is not observed under this condition. $\mathrm{NO}_{2}$ emission increases slightly with electric power output. $\mathrm{N}_{2} \mathrm{O}$ emission is quite low level. $\mathrm{NH}_{3}$ emission is negligible. Combustor liner temperature keeps below 1,000 degrees C. Therefore, redesigned liner cooling structure is effective.

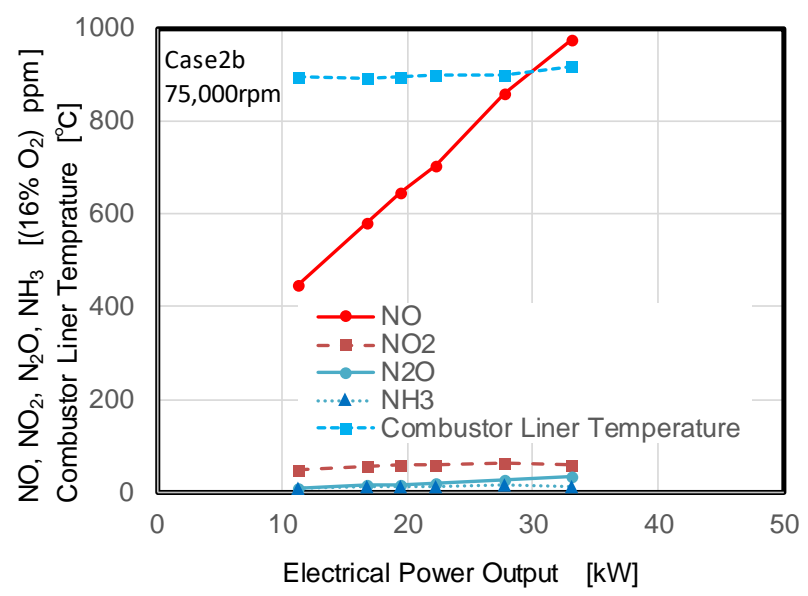

Figure 4. Emission and combustor liner temperature (75,000rpm, Case2b)

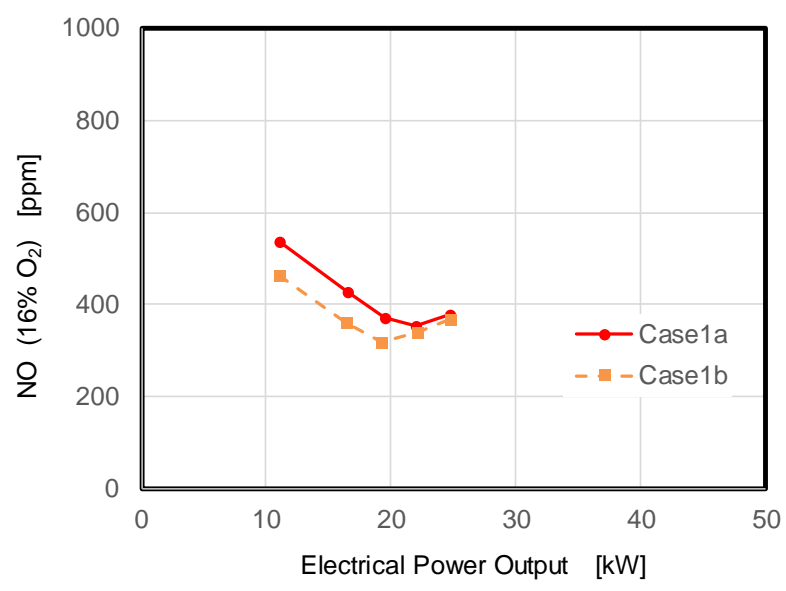

Figure 5. NO emission (75,000rpm, Case1) 
Since the trend of NO emission determines the total NOx emission, comparison of $\mathrm{NO}$ emission in several cases are carried out as show in figure 5-6. Case 1a and Case1b shows NO reduction effect and NO emission takes local minimum around $20 \mathrm{~kW}$ of electrical power output. In the case of step1, NO emission takes local minimum around $20 \mathrm{~kW}$ of electrical power output when area of secondary dilution holes is 1.5times of step0. Air flow rate through swirler of step2 may be lower than that of step1.

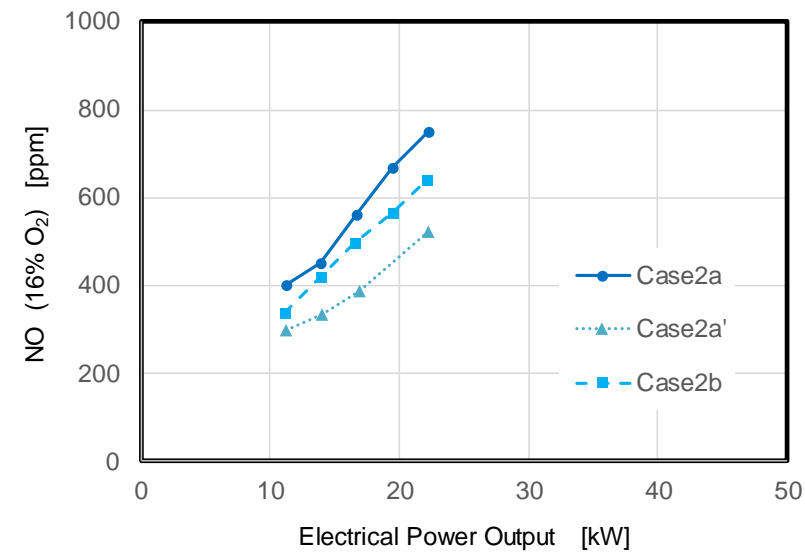

(a) 70,000rpm

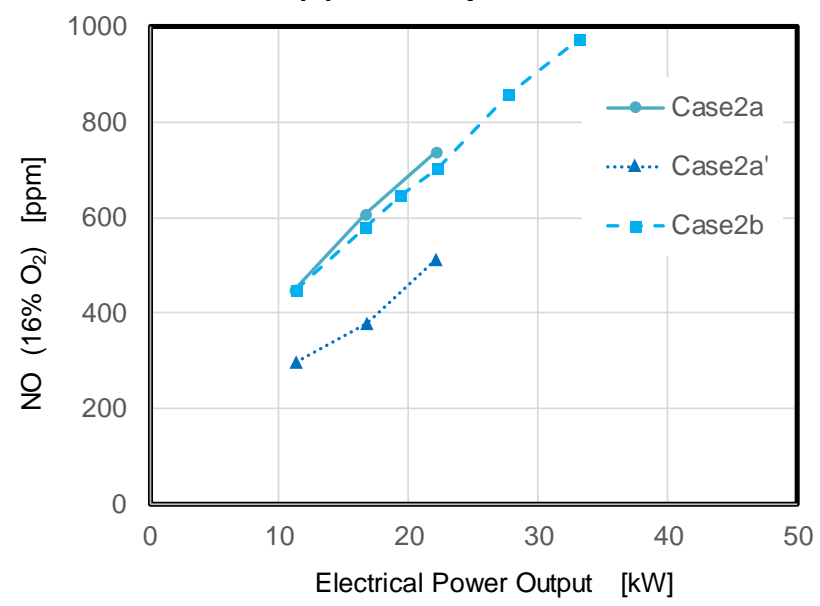

(b) 75,000rpm

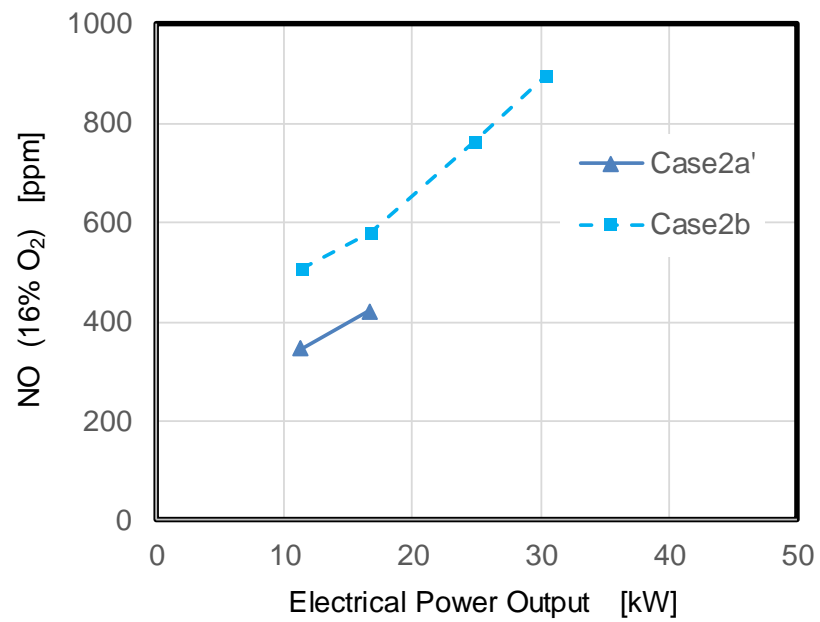

(c) $80,000 \mathrm{rpm}$

Figure 6. NO emission (Case2)
In the case of case2, NO emission increases with electrical power output at every rotating speed. Therefore, combustor liner cooling air structure may reduce air flow rate through air swirler. This means the ratio of the combustion air flow rate of the primary combustion zone and the secondary combustion zone may be changed. NO emission in case $2 \mathrm{a}$ and case $2 b$ are larger than that in case $2 a$ '. This means gas fuel nozzle size is also important parameter.

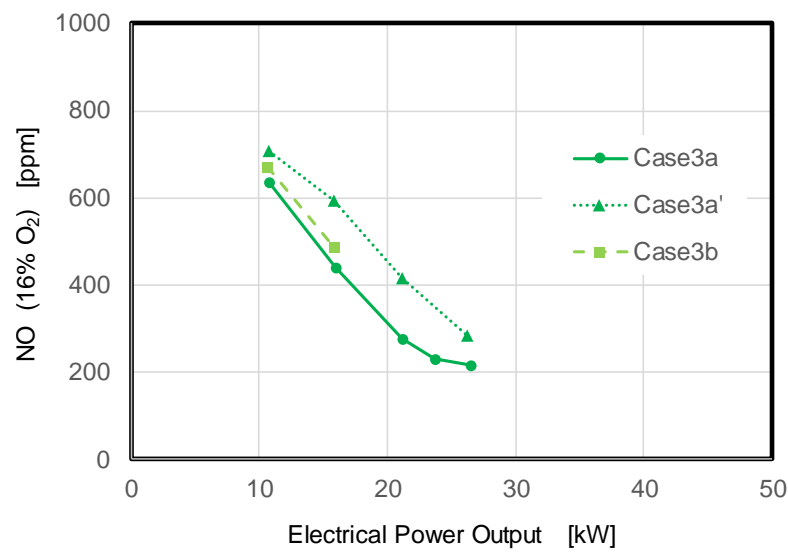

(a) $70,000 \mathrm{rpm}$

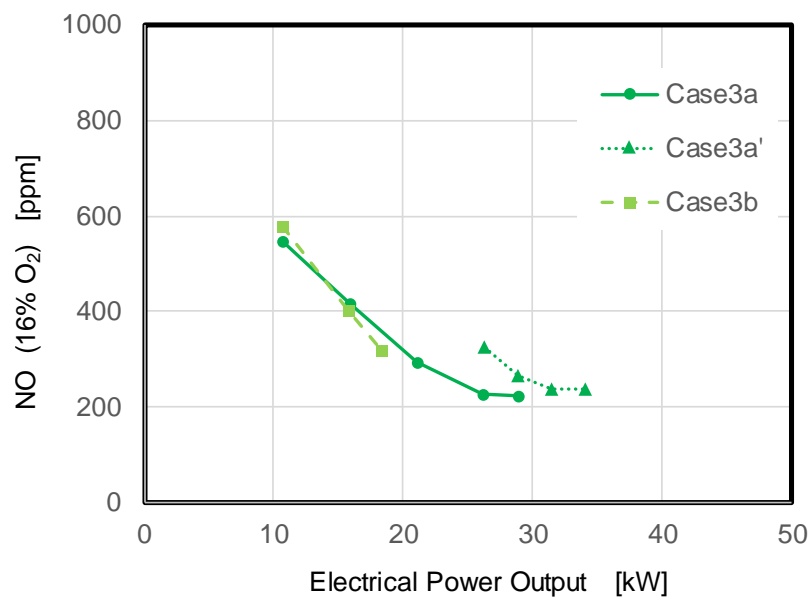

(b) 75,000rpm

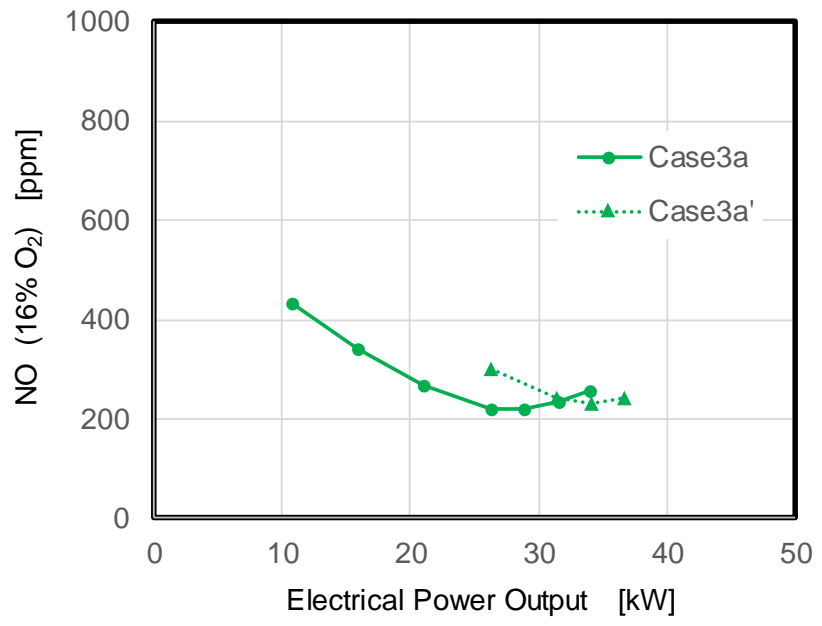

(c) 80,000rpm

Figure 7. NO emission (Case3) 
In order to increase air flow rate through air swirler, area of air swirler in case 3 is set as same as that of step0. Figure 7 shows the NO emission in case3. NO reduction effect is observed around $30 \mathrm{~kW}$ of electric power output. NO emission in case $3 \mathrm{a}$ and case $3 \mathrm{~b}$ are almost same and they are smaller than that in case $3 \mathrm{a}$. The minimum value of NO emission is $221 \mathrm{ppm}$ at $16 \% \mathrm{O}_{2}$ and the minimum value of $\mathrm{NO}$ emission is $241 \mathrm{ppm}$ at $16 \% \mathrm{O}_{2}$. This value means that $\mathrm{NO}$ emission can be reduced to $1 / 4$ or less as compared with before redesigning for rich-lean combustion.

Above results means resistance of the original swirler is not small enough with the combustor liner cooling structure of step2. Therefore, NOx emission reduction near higher electrical power output requires reduction of area of secondary dilution air holes and/or improvement of air swirler. Reduction of area of secondary dilution air holes increases the pressure loss of the combustor and reduces the efficiency of gas turbine. Therefore, improvement of air swirler is desirable.

\section{SUMMARY}

Low-NOx combustor (Step2) was designed using knowledge of Prototype bi-fuel combustor for ammonia (Step0) and low-NOx combustor (Step1). As a result, we found a condition that the NO emission can be reduced to $1 / 4$ or less as compared with before redesigning for rich-lean combustion.

1. The redesigned liner cooling structure of low-NOx combustor (Step2) is effective.

2. The redesigned liner cooling air structure may reduce air flow rate through air swirler.

3. NO emission can be reduced to $1 / 4$ or less as compared with before redesigning for rich-lean combustion.

\section{ACKNOWLEDGMENTS}

This work was supported by the Council for Science, Technology and Innovation (CSTI), Cross-ministerial Strategic Innovation Promotion Program (SIP), "Energy Carriers" (Funding agency: JST).

The authors also thank to Mr. Imura, Mr. Okada, Prof. Komiya, Mr. Kataoka for the operation of micro gas turbines.

\section{REFERENCES}

Evans, B. (2013). Using Local Green Energy and Ammonia to Power Gas Turbine Generators. the tenth Annual $\mathrm{NH}_{3}$ Fuel Conference

Hayakawa, A., Goto, T., Mimoto, R., Arakawa, Y., Kudo, T., Kobayashi, H., (2015a). Laminar burning velocity and Markstein length of ammonia/air premixed flames at various pressures. Fuel, 159 (1) 98-106

Hayakawa, A. Goto, T., Mimoto, R., Kudo, T., Kobayashi, H., (2015b). NO formation/reduction mechanisms of ammonia/air premixed flames at various equivalence ratios and pressures. Bulletin of the JSME, Mechanical Engineering Journal, 2 (1) 1-10
Iki, N., et al, (2014). Micro Gas Turbine Operation with Kerosene and Ammonia. 11th annual $\mathrm{NH}_{3}$ Fuel Conference

Iki, N. et al, (2015a). Micro Gas Turbine Firing Kerosene and Ammonia. ASME Turbo Expo 2015, , GT2015-43689

Iki, N., et al. (2015b). Micro Gas Turbine Firing Ammonia", 12th annual $\mathrm{NH}_{3}$ Fuel Conference,

Iki, N., et al. (2016a). Micro Gas Turbine Firing Ammonia. ASME Turbo Expo 2016, GT2016-56954

Iki, N. et al. (2016b). Gas Turbine Power Generation Firing Ammonia-Methane Mixture. Proc. of the Asian Congress on Gas Turbines ACGT 2016, ACGT2016-104

Iki, N. et al. (2017a). Operation and Flame Observation of Micro Gas Turbine Firing Ammonia. ASME Turbo Expo 2017, , GT2017-64250

Iki, N. et al. (2017b). Gas turbine power generation system firing ammonia and natural gas. WHTC 2017

Iki, N. et al, (2017c). Development of a gas turbine power generation system firing ammonia gas. PBEC 2017

Iki, N., et al. (2018). NOx Reduction in a Swirl Combustor Firing Ammonia for a Micro Gas Turbine. ASME Turbo Expo 2018, , GT2018-75993

1Ito, S., Kato, S., SAITO, T., Fujimori, T., Kobayashi, H. (2015). 53rd Symposium (Japanese) on Combustion, (A323) 380-381

Ito, S., Kato, S., SAITO, T., Fujimori, T., Kobayashi, H. (2016). 54rd Symposium (Japanese) on Combustion, C332

Kurata, O. et al, (2015). Power Generation by a Micro Gas Turbine Firing Kerosene and Ammonia. icope 2015, , ICOPE-15-1139

Kurata, O. et al. (2017a). Performances and emission characteristics of $\mathrm{NH}_{3}$-air and $\mathrm{NH}_{3}-\mathrm{CH}_{4}$-air combustion gasturbine power generations. Proc. Combust. Inst. Vol. 36, Issue $3,, 3351-3359$

Kurata, O. et al. (2017b). Proc. the ASME 2017 Power Conference Joint with ICOPE-17, POWER-ICOPE2017-3277

Kurata, O. et al. (2019). Development of a wide rangeoperable, rich-lean low-NOx combustor for $\mathrm{NH}_{3}$ fuel gasturbine power generation. Proc. Combust. Inst., (https://doi.org/10.1016/j.proci.2018.09.012)

Pratt, D.T., (1967). Performance of Ammonia-Fired GasTurbine Combustors. Technical Report No.9 DA-04-200AMC-791(x)

Solar Division of International Harvester Company (1968). Development of an Ammonia-Burning Gas Turbine Engine. Final Technical Report DA-44-009-AMC-824(T)

Somarathne, Kunkuma, K. D., Hayakawa, A., Kobayashi H. (2016). Numerical investigation on the combustion characteristics of turbulent premixed ammonia/air flames stabilized by a swirl burner. Bulletin of the JSME, Journal of Fluid Science and Technology, 11 (4) 1-10

Somarathne, Kunkuma, K. D., Hatakeyama, S., Hayakawa, A., Kobayashi H., (2017).

Numerical study of a low emission gas turbine like combustor for turbulent ammonia/air premixed swirl flames with a secondary air injection at high pressure. Int. Journal of Hydrogen Energy, $1-12$ ( https://doi.org/10.1016/j.ijhydene.2017.09.089) 
Uchida, M., Ito, S., Kato, S., SAITO, T., Fujimori, T. (2016). 54rd Symposium (Japanese) on Combustion, C333

Valera-Medina, A., Morris, S., Runyon, J., Pugh, D., Marsh, R., Beasley, P., Hughes, T. (2015). Ammonia, Methane and Hydrogen for Gas Turbines. Energy Procedia, , (75) 118-123

Valera-Medina, A., Marsh, R., Runyon, J., Pugh, D., Beasley, P., Hughes, T., Bowen, P. (2017). Applied Energy, , (185) 1362-137

Valera-Medina, A., Xiao, H., Owen-Jones, M., David, W.I.F., Brown, P.J. (2018). Ammonia for power. Progress in Energy and Combustion Science 69 63-102 